\title{
Allo A 親和性糖蛋白質カラムによる不必要な抗体の除去
}

\author{
梅津和夫*・湯浅＼cjkstart勲**・鈴木庸夫*
}

\begin{abstract}
SUMMARY
A method for removing of unnecessary antibodies was developed. Allo A lectin-Sepharose $4 \mathrm{~B}$ and its binding serum glycoproteins were crosslinked by the dimethyl suberimidate. The antibodies on the market were purified by affinity chromatography on glycoproteins-allo A-Sepharose. By the method, anti- $\alpha_{1}$-antitrypsin, anti-hemopexin and anti-transferrin were obtained from the eluted fraction, and anti-retinol binding protein was obtained from the nonretarded fraction. On the other hand, anti-factor I and anti-Gc-globulin were obtained from both fractions. The method proved to be excellent for removing unnecessary antibodies from so called monospecific antibody on the market.
\end{abstract}

Key words : antibody, allo A lectin, immobilized glycoprotein, affinity chromatography.

はじめに

最近の分析技術の向上は目覚ましいあのがある.とれ に伴って市販されているポリクローナルの特異的抗血清 には別の抗原に対する抗体む同時に検出されるととが多 くなり，誤った結果を導き出している報告例む少なくな い. 実際にはいろいろのメーカーの抗血清を比較して目 的にあうロットを選びだしたり，抗血清をさらに精製せ ざるをえないことも多い，抗体中の不必要な抗体の吸収 除去操作は主として不溶化した抗原で行うが，乙の抗原 の調整はなかなか容易ではない.

そこで, allo A レクチンの選択的糖蛋白質との結合 性に着目し，乙れを抗血清の精製の目的に応用するた め, 固定化 allo A レクチンゲルに親和性糖蛋白質を 結合させた後, 架橋剂で両者を共有結合させたゲルを用 いたアフィニティクロマトグラフィで, 市販の抗血清を 非吸着分画之溶出分画とに分離し，両分画におりる抗体 の特異性を検討した.

\section{実験材料および方法}

\section{1. 抗血清}

次の抗血清を使用した. 和光純薬の抗 factor I (IF) 血清; Lot No. PEK 9751, Dako 社の抗 retinol binding protein (RBP) 血清; Lot No. 019D, 抗 Gcglobulin (GC) 血清; Lot No. 039F，および抗 $\alpha_{1}$ antitrypsin (PI) 血清; Lot No. 032F.

\section{Allo A-Sepharose ゲル}

Allo A レクチン1) (コスモ・バイオ社) を $\mathrm{BrCN}$ 活 性化 Sepharose 4B (Pharmacia 社) そゲル $1 \mathrm{ml}$ 当り $5 \mathrm{mg}$ 結合させ, allo A-Sepharose ${ }^{2)}$ を作製した.

\section{Allo A 親和性糖蛋白質を固定化したゲルの作製}

$1.5 \mathrm{ml}$ の allo A-Sepharose を小カラムに詰め, 2 倍に希釈した 3 人分の混合ヒト正常血清 $3 \mathrm{ml}$ を加えて 親和性糖蛋白質を反応させ， $20 \mathrm{ml}$ の PBS で洗浄した. このゲルを試験管に移し， $0.1 \mathrm{M}$ ホウ酸 buffer, $\mathrm{pH} 8.0$ で一度遠心洗浄を行い, 同 buffer $2 \mathrm{ml}$ に $10 \mathrm{mg}$ のジ

Removing of unnecessary antibodies by affinity chromatography on immobilized allo A lectin-bind-: ing glycoproteins.

* Kazuo Umetsu, Tsuneo Suzuki; 出形大学医学部法医学

** Isao Yuasa; 鳥取大学医学部法医学

Correspondence address: Kazuo Umetsu, Department of Forensic Medicine, Yamagata University School of Medicine, Iidanishi, Yamagata 990-23, Japan.

（受付 1989 年 8 月 11 日，受理-1990年 2 月 19 日） 
メチルスベルイミノ酸（和光純薬）を加えたあのと混合 して, allo A と親和性蛋白質の共有結合を, 振とう しながら室温で 30 分間行った. ついで, $1 \mathrm{M} \mathrm{NaCl}$ を 含む $0.1 \mathrm{M}$ 酢酸 buffer, $\mathrm{pH} 4.0$ と $0.1 \mathrm{M}$ ホウ酸 buffer, pH 8.0 で交互に 2 回ずつ洗浄して, 不完全結 合の蛋白質を除去後に PBS で平衡化した.

\section{4. 抗血清のアフィニティクロマトグラフィ}

a. 抗 IF 血清

$0.5 \mathrm{ml}$ の $0.1 \mathrm{M}$ lactose を含む PBS で 50 倍に希 釈した抗 IF 血清を注射筒に詰めた $1 \mathrm{ml}$ の吸着体に対 して自然落下で 3 度循環させ, 最後に $1.5 \mathrm{ml}$ の $\mathrm{PBS}$ で洗浄した液を非吸着分画とした．ついで $8 \mathrm{ml}$ の PBS で洗浄後, $2 \mathrm{ml}$ の $0.1 \mathrm{M}$ グリシン- $\mathrm{HCl}$ buffer, $\mathrm{pH} 2.6$ を加えて，吸着成分を解離させ，ただちに $0.5 \mathrm{M} ト リ$ ス $-\mathrm{HCl}$ buffer, $\mathrm{pH} 9.0$ を少量加え $\mathrm{pH}$ を中性に戻し た. これを溶出分画とした。

\section{b. 混合抗血清}

$0.5 \mathrm{ml}$ の $0.1 \mathrm{M}$ lactose を含む $\mathrm{PBS}$ に抗 $\mathrm{RPB}$ 血 清および抗 GC 血清は 50 倍, 抗 PI 血清は 200 倍に なるように希釈したものを混合抗血清とし， $1 \mathrm{ml}$ の吸 着体汶対して抗 IF 血清と同様の操作により, 非吸着分 画と溶出分画の抗体を得た。

\section{Immunoblotting 法}

SDS-ポリアクリルアミドゲル電気泳動 (SDS-PAGE) は Laemmli の方法3) PAGE は還元剂非存在下で, 1 レーン当り $0.5 \mu 1$ のヒ 卜血清を含むように泳動を行った，泳動終了後，Immobilone-P (Millipore 社) に電気的に転写を行った. 一部のレーンは CBB-R 250 で染色した. 残りは $2.0 \%$ のスキムミルクでブロックした，ついで上記の非吸着， 溶出分画を希釈せずそのまま室温で 30 分間反応させ, 洗浄後, 500 倍に希釈した Dako 社のペルオキシダー ゼ標識抗ウサギ免疫グロブリン血清を 30 分反応させた. 洗浄後, ジアミノベンチジン染色を行った. なお対照と して, 未処理の個々の抗血清との反応屯行った.

\section{結果および考察}

抗 IF 血清の immunoblotting による分析パターン を Fig. 1 に示した. 抗 IF 血清中には抗 IF 以外にあ 少なくとも抗 transferrin (TF) および抗 hemopexin （HX）の抗体が含まれているととがわかった．乙の抗血 清は allo A 親和性蛋白質を固定化したゲルでの吸着操 作により，非吸着分画ではほぼ抗 IF 血清のみを含む画 分となり, 吸着溶出分画にはじめの抗血清と同様の抗体
が検出された。これまで TF や HX は allo A 親和性 血清蛋白質であるとされている゙2が，IF についてはデー タがなかった. しかし，吸着溶出分画中の抗血清にあ抗 IF 抗体が含まれていたととは，IF もまた allo A 親 和性糖蛋白質であることを示している．乙れは正常血清 中の IF 量は $0.034 \mathrm{mg} / \mathrm{ml}$ とかなり低濃度である゙)の で吸着体に固定化された IF 量はきわめて微量であるた め，抗 IF 血清中の抗 IF 抗体を完全に吸収しきれなか ったためと考えられる.なお allo A 親和性蛋白質と して血清中に高濃度に存在する $\mathrm{TF}$ や $\mathrm{HX}$ は, 吸着 体に多く固定され，また 抗 IF 血清中でこれらの抗体 の力価が低功たものと考元られると加ら，との二つ の抗体は容易に吸収されたのであろう.

つぎに，allo A 非親和性蛋白質である RBP および $\mathrm{GC}$ ，親和性蛋白質である $\mathrm{PI}^{22}$ に対する混合抗体を用い て，今回作製した吸着体を検定した，その結果を Fig. 2 に示した．対照として行ったてれら三種の市販のすべて の抗血清中にあ, 表示している特異的抗体以外のあのに よるあのと見られるバンドが検出されたが，とくに抗 RBP 血清に扔いては高分子量蛋白質に対する多くの抗 体の存在が示された．乙れらの反応は蛋白質のポリマー 化や分解，変性あるいは共通抗原によるあのではなく， 大部分は目的外の抗体の混在によると考えられた．乙れ ら 3 種類の混合抗血清を allo A 親和性蛋白質を固定化 した吸着体でアフィニティクロマトグラフィを行った. 非吸着分画には BRP および $\mathrm{GC}$ ，それにわずかに $\mathrm{PI}$ の付近のバンドを染色する抗体が含まれていた．乙の分 画には目的外の抗体と考えられた高分子量に対する抗体 はほとんご検出されなかった，一方，吸着溶出分画には 打むにPI と高分子領域の蛋白に対する目的外の抗体 と，弱いながら GC に対する抗体が検出された。

GC には糖鎖末端にシアル酸をまったくむたない GC 2 型と，一部の分子にシアル酸をあつ GC 1 型に分類 される ${ }^{5)}$. 一方, allo A レクチンは Gal $\beta 1-4 \mathrm{GlcNAc}$ グループに特異性をもち，とくに Neu5Ac $\alpha 2-6 \mathrm{Gal} \beta 1$ 4GlcNAc 亿強い親和性をむつととが知られている6 したがって，以前の報告 ${ }^{2}$ で GC は allo A 非親和性 蛋白質に分類したが，GC の一部はこのシアル酸を有す る糖鎖をもつととから，allo A は GC 1 型の一部に強 い親和性を示すととが推定され，今回のような結果とな ったものと思われる．GC 2 型の血清のみを選んで作製 した吸着体を用いれば，抗 $\mathrm{GC}$ は非吸着分画に検出され るものと推定される，市販の各血清成分に対する抗血清 中にはとくに表示以外の抗体として抗 $\mathrm{GC}$ 抗体が検出さ 


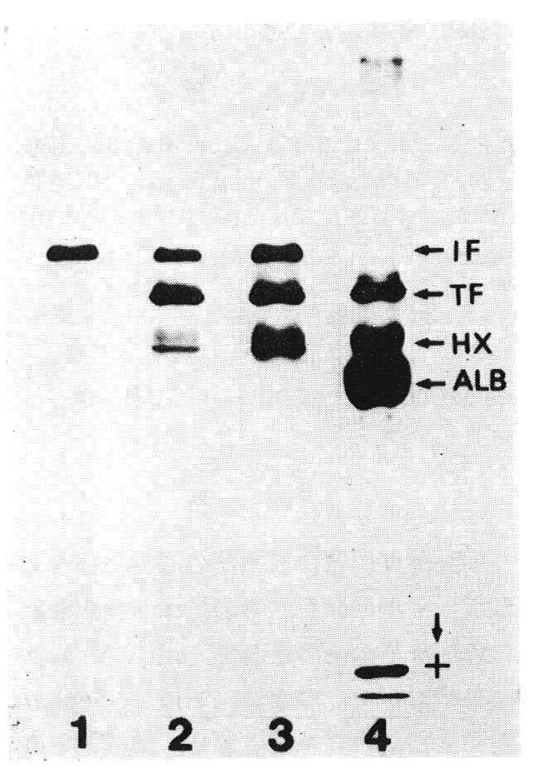

Fig. 1. Lanes 1 and 2, immunoblotting patterns of human serum proteins with anti-IF serum treated with the glycoproteinsallo A-Sepharose column (lane 1, column drop-through; lane 2, column eluate); lane 3 , those with starting anti-IF serum, $1 / 200$; lane 4 , human serum protein patterns stained with CBB-R 250.

About $0.5 \mu 1$ of each human serum was loaded.

机るととが多いが，この抗 GC 抗体の除去には本法が有 効であるととが示唆された。

なお，市販の抗血清を高感度の検出方法にて用いる場 合は，抗血清を高倍率飞希釈するととなどにより目的外 の反応を押えることが多いが，この方法は微量成分に対 する抗体の場合は適用がむずかしいあるかじめ少なく 之も SDS-PAGE 等で目的外の抗体の有無および性質の 確認がデータの信頼性を向上させるための必須条件之考 えら机る、今回，レクチンを利用して親和性糖蛋白質を 固定化した吸着体を用いる方法は特異抗血清中の不必要 な抗体の除去のために有効であることが示された. なお 血清蛋白質の大部分を占める albumin と $90 \%$ 程度の IgG が allo A 非親和性蛋白質である ${ }^{2)}$ ととに加えて, その他の蛋白質もレクチン親和性の有無によって分別さ れ効率よくゲルに固定化できる本法は，抗血清の精製の ためには簡便な方法と考えられる. またとの方法は血清 蛋白質に対する抗体以外飞も単純蛋白質と糖蛋白質に対 する抗体を分別する際にも有効であるう.

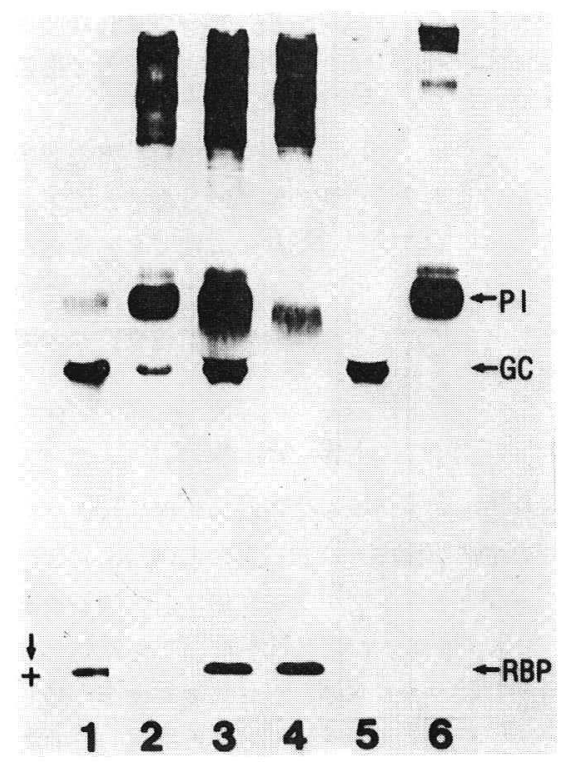

Fig. 2. Lanes 1 and 2, Immunoblotting patterns of human serum proteins with mixed antibodies (anti-RBP, anti-GC, and antiPI) treated with the glycoproteins-allo A-Sepharose column (lane 1, column drop-through; lane 2, column eluate); lane 3 , those with starting mixed antibodies; lane 4-6, control (lane 4, human semum protein patterns stained with anti-RBP serum, 1/200; lane 5, those stained with anti-GC serum, 1/200; lane 6 , those stained with anti-PI serum, $1 / 800)$.

About $0.5 \mu \mathrm{l}$ of each human serum was loaded.

本法では allo A レクチンと親和性糖蛋白質を共有結 合させたが，完全に結合していない糖蛋白質を酸とアル カリ溶液により洗浄除去する際に少なからずの蛋白質の 脱落が認められた，とれは，レクチンと糖蛋白質との特 異的結合はレクチンの蛋白質と糖蛋白質の糖鎖の結合で あるが，架橋剂で反応させてもこの両者はこの部位では 架橋されず，レクチンの蛋白質と糖蛋白質の蛋白質部分 との結合となるために効率がやや悪くなるためと推定さ れた。な打 allo A-Sepharose カラムで allo A レクチ ンに親和性を有するヒト血清中の糖蛋白質を分離し，こ の蛋白質を $\mathrm{BrCN}$ 活性化 Sepharose に固定化したゲ ルを作製し，同様の抗体を用いてアフィニティクロマト グラフィを行ったととろ，上記とまったく同じ結果を得 るととができた，との方法は操作がやや複雑であるが， 


\section{（210）生物物理化学}

長所としてはより多量の糖蛋白質の固定化が可能なとと や，抗体希釈液に lactose の添加が不必要であるととな どである.

以上のように，allo A 親和性糖蛋白質を固定化した ゲルを用いる本法は市販の特異的抗血清から不必要な目 的外の抗体の除去等に有効な一方法であるととが示され た．今回は allo A レクチンの有用性を示したが，種々 のレクチンを用いても抗体の純化や免疫抗原の調整等へ の活用が期待される.

\section{まと め}

分析技術の向上に伴って市販の特異的抗血清の中には 目的外の抗体が検出されることが多い，不必要な抗体除 去の一方法としてレクチンを利用する方法を検討した. Allo A-Sepharose に親和性糖蛋白質を反応させ，つい で架橋剤で両者を共有結合させた吸着体を作製し，この ゲルを用いてヒト血清成分に対する特異的抗血清をアフ 1ニティクロマトグラフィで分析したととろ，基本的に はレクチン親和性糖蛋白質に対する抗体はこのゲルに吸 着され；また非親和性糖蛋白質に対标る抗体は吸収され なかった．よって本法は，自的外の抗体の除去等におけ る有力な一方法となりうるととが判明した.

本論文の要旨は第 38 回電気泳動学会総会（1987 年
10月，盛岡）において発表した。

\section{文献}

1) Umetsu, K. et al. : J. Biochem., $95: 239,1984$.

2) Umetsu, K. et al. : Biochem. Int., $10: 549,1985$.

3) Laemmli, U. K. : Nature, 227:680, 1970.

4) Pungburn, M. K. et al. : J. Exp. Med., 146: 257, 1977.

5) Cleve, H. and Patutschnick, W. : Hum. Genet., $47:$ 193, 1979.

6) Yamashita, K. et al.: J. Biol. Chem., 263: 17482, 1988.

\section{要旨}

数多くの高感度の蛋白検出法の開発に伴って市販の特 異的抗血清のなかには目的外の抗体が検出されることが 多い. 乙の解決法の一つとして allo A レクチンを用 いる方法を検討した. つまり, allo A-Sepharose に血 清中の親和性糖蛋白質を反応させ，架橋剂で両者を共有 結合させた，乙の吸着体を用いて，市販のヒト血清成分 に対する特異的抗血清をアフィニティクロマトグラフィ で分析したところ，ほぼ親和性糖蛋白質に対する抗体 はこのゲルに吸着され，また非親和性蛋白質に対する抗 体は吸収されなかった，以上より，本法は特異的抗血清 の調整における有力な一方法となりうることが判明し た. 